\title{
Chapter 4 \\ Captain Kirk, Managers and the Professionalization of Safety
}

\author{
Hervé Laroche
}

\begin{abstract}
Historically, management as a means for governing business organizations has developed at the expense of professions as autonomous, self-regulated bodies. Therefore, the current call for "professionalization" in the domain of safety might be surprising. This chapter explores this apparent contradiction in the form of an imaginary dialogue between an operator and a manager. The current "injunction to professionalism" is critically assessed. Alternative views of professionalization are developed, with implications for alternative managerial roles.
\end{abstract}

Keywords Managerialization • Accountability • Empowerment

\section{O: Operator}

\section{M: Manager}

M: The company will shortly launch a training program for improving safety.

O: Another boring series of sessions with a guy who knows nothing about my job. More stupid slides that would make a five year old cry.

M: I know, you've had too much of that. This time it's different. It's not only about rules, more about a "professionalization of safety".

O: Professionalization?

M: Yes. Precisely, not taking you as a five year old but rather as a professional who should know what he's doing and why.

This chapter takes the unusual form of a dialogue between an operator and his manager in an industrial company (with a concern with safety). It deliberately takes a critical stance towards the idea of professionalization. This does not reflect my entire views on the topic. In fact, I share many ideas that are developed elsewhere in the book and that do not need to be reiterated. The critical ideas expressed by the operator and his manager do, however, reflect some of my opinions, though I push them to the extreme for the purpose of debate and also for fun.

\footnotetext{
H. Laroche $(\bowtie)$

ESCP-Europe, Paris, France

e-mail: laroche@escpeurope.eu

(C) The Author(s) 2018

C. Bieder et al. (eds.), Beyond Safety Training, Safety Management, 
O: I know what I'm doing and why. More than you do.

M: Let's not argue.

O: What you really want is for me to do what you want me to do, without you having to tell me.

M: It's not only me. My bosses. The customer. The HSE department. The inspectors. You know.

O: Lots of people with lots of different ideas about how I should do the job. And everybody trying to cover their own ass.

M: Please.

O: Look, I know you're doing your best. But when I hear that kind of stuff about "professionalization of safety" or whatever, I find it hard to take it seriously.

M: Why?

O: Since I've been working here, there have been more rules and norms every day. Plus auditing, reporting, paperwork. Nobody wants me to be a professional. Everybody wants me to comply with things nobody asked me about before. Including stupid rules and pointless norms that prevent me from doing a better job. You know very well that I could do a much better job. And a safer one, too.

M: That's what this program is about!

O: Really? You're going to let us operators organize the work?

M: Well... not quite. But I promise you, we'll discuss any issue you'll raise.

O: See? You managers don't want professionals. You never did. More than that: management is all about substituting abstract rules and norms for tacit knowledge. It's about replacing self-organizing workers with individuals complying to standards and orders. It's been like that since good old Winslow E. Taylor.

M: This is not like that anymore.

O: Yes it is! More and more! You're even doing this to the eggheads now. In hospitals, universities, law firms. Extracting and commodifying their knowledge, restricting autonomy, evaluating through your own standards of quality and productivity. Of course, you have to accept some degrees of autonomy. After all they're doing the real job, you need them. But every bit of power you can take away from them, you take it.

M: How do you know about all this?

O: I read the Sunday papers. The truth is, managerialization is just incompatible with professionalization. The drive for professionalization is normally from within a community of equals. They organize themselves to gain credit and define their own territory. Sociologists call this a jurisdiction (Abbott 2014).

M: Why is it different in our case?

O: Well, the call for professionalization comes from above. It's a top-down injunction to professionalize (Boussard 2009). An oxymoron, to some point. Though not exceptional. Managerialization often comes with a discourse about professionalization. This is strange, when you think of it. That's why I'm suspicious.

M: You forget that managers have to demonstrate that the organization complies with external norms and standards. Not mentioning the expectations of customers, governments, the press, and the public at large. 
O: You're right. The injunction for professionalism comes also from outside. It's passed on to the managers.

M: Funny, when I was in India it was the workforce who called for more professionalism from their managers! Mostly they were speaking out against nepotism, abuses, harassment, and a general lack of managerial skills. You see, there's also pressure from below (Vaidyanathan 2012).

O: Thanks for the idea. We should do that to.

(They laugh.)

M: So why would the company top management launch a program called "professionalizing safety"?

O: They're clever guys. They sell old stuff in a new bottle. Good idea, really. Everybody wants the guy who handles the risky stuff to be a "professional", whatever this means. And among the workforce, who can oppose a professionalizing program? Some of my worker buddies might even fall for it.

M: Well isn't it truly appealing?

O: I'm not buying. It's a trick. It's patting you on the shoulder. It's chocolate medals. Some guys, they called this "grandiosity" (Alvesson and Gabriel 2015). This is another thing you managers are very good at. Calling things by a fancy name. Take Mission Statements for instance. Dedication. Commitment. Serving the community. Social responsibility. Company culture. Professionalism.

M: OK, you have a point. I resent that too.

O: I know. Otherwise I would not even talk to you.

M: See, they want me to be a leader, not just a manager. We had a training about leadership skills, you know. We had this lecture about great leaders, Alexander, Julius Caesar, Churchill... Even Napoleon!

(They laugh.)

O: So you feel better as a leader?

M: No. (Sighing) Sometimes I feel like a subordinate on the Enterprise...

O: You mean, the starship in the Star Trek series?

M: Yes. You have this Captain Kirk, really quite a nice guy, saying "Make it so" whenever he has reached a decision. In the series, you never see the poor guy who actually "makes it so". That's me. I have to "make it so" without bothering Captain Kirk with the details. This is what I'm paid for. If I escalate a problem my boss quickly reminds me about that.

O: They just want to mind their business without hearing from us down below.

M: Most of the time they just don't want to hear about what's wrong. Especially if it's really a tricky issue and if it does not align with their objectives, policies, and all. One thing they really hate is being confronted with their own contradictions and their powerlessness, because of a lack of skills or knowledge or budget or resources or influence or courage or whatever.

O: That's the point. That's why they come up with this professionalization idea. They think that if we're better trained, if we have better skills, they won't hear from us, safety-wise. Because professionals don't complain, they solve issues at their level. That's why they want professionals. Only they don't really want professionals. They just don't want problems coming to their attention. 
M: You're probably right...

O: And in the end, me and my work buddies end up with the nasty details. Like having to violate safety rules for the purpose of productivity.

M: Yes. I try to avoid it but most of the time I can't do otherwise.

O: That's not new. This is how big companies work. It's called "pushing down the details" (Jackall 1988). It hides the fact that managers often don't know how to solve issues or don't want to solve them because it would acknowledge that wrong choices and inadequate policies have been implemented. It hides contradictions within the organization. "Professionalism" boils down to a general injunction to handle the details. It's the same "Make it so!", only wrapped within an abstract, supposedly appealing discourse of special skills and abilities.

M: Yet there might be something to take from it. What would that be, then, truly professionalizing safety?

O: I'll tell you a story (Hampden-Turner 1990). In another life, I was a truck driver for an oil and gas company in the Rocky Mountains. Yes, the wild, wild West. And the truck I was driving was a tanker. We had bonuses and penalties for delivering to the gas stations in time. We were proud of being professional truck drivers. Safety was not a priority. Violations when loading or unloading were the rule. Speed limits on the highway and through the small towns were optional. We did everything to speed up the process. Management had tried everything. Big books of rules that nobody read. Inspectors that everybody knew how to fool. Endless training sessions that sounded like Sunday school. One day the guy who did the training was so rudely pushed around that he ran away in tears and filed a complaint. The drivers didn't care. They thought that risk was part of the job and that they should take it like a man takes life: in his own hands.

M: Like a shotgun.

O: Exactly. One day an elderly guy came and called for a meeting. We thought it was another silly training session. But the guy said he had nothing to teach us about safety, only that we did not behave safely. He said that parents were afraid that their kids would get run over when a tanker rushed by their homes. He said that gas station attendants and all their neighborhood feared that one day a tanker might blow up when unloading. He said that we were a hazard for everybody in the country. Then he listened to us. We said that the schedules were too tight; that many safety procedures were stupid; that the trucks themselves were poorly equipped; that the roads were dangerous; that we had to make a living. We shouted at him but we were ashamed. Then he left. He came back a week later with some guys from the State Road Service, an expert from the technical department, a guy from a truck company, and a couple of gas attendants. We formed committees of volunteers on a variety of themes. We held meetings in towns with the population. We proposed roadwork projects, design ideas for safety devices, a system for establishing delivery schedules, principles for bonuses and penalties, and we participated in the writing of all safety procedures. We committed to reporting violations to an elected group among us. They decided on the sanctions. We still saw ourselves proudly as professional truck drivers. We still thought that risk was part of the job and that we 
should take it like a man takes life: in his own hands. Only this had a different meaning.

M: Nice story. You should sell it to Hollywood. (Imitating an advertisement) Now a major movie, starring Kris Kristofferson!

O: That's what professionalism means. Not only training, not only safety. Empowerment and autonomy. For that managers have to relinquish a lot of their own power. There is no way such empowerment can be limited to specific aspects of the work, such as safety. Safety is a way of doing the work, not an add-on to the tasks. So, empowerment has to encompass the work as a whole.

M: OK... Do I still have a job?

O: Sure. It depends on what you managers want for yourselves. You can be the guy who came to speak to the drivers. You can actively participate in the activities of professionalization. For instance, you can initiate, organize, validate the processes through which the norms and practices are put into coherence by the operators. In doing so, you managers could retain some control over the empowering process and its outcomes.

M: True, but I would have to advocate for substantial changes in norms and practices that can be difficult to accept for upper management levels and/or for outside authorities or stakeholders. And I would be held accountable for the resulting norms and practices.

O: Right. But isn't that what you're paid for?

M: Not that trick again!

O: If you don't like that you can keep your distance with us operators. Operators would have to adapt practices to real-world constraints and find out the best possible trade-offs. As professionals, they would have to regulate themselves so that errors, accidents and violations are kept to a minimum. Or at the very least, they should see that these unwanted events are confined within a restricted area of confidentiality. You managers, in turn, would take charge of the various stakeholders. Your job would be to dress up a convincing window of compliance that would keep authorities and stakeholders satisfied. In short, you would have to erect a protective barrier in order to enable autonomous operators to efficiently do their job. Occasionally you would have to cover up errors and violations (at least what could be identified at as such by an outsider), as long as the real stuff is taken care of.

M: The obvious limitation of this strategy is that things can get out of control. In case of a major failure, exposure will be maximum.

O: Yes. The difference with "true" professions like health specialists is that lower-level operators will never be held fully accountable. In case of a major failure, management will take the blame (which is only normal).

M: I'm not keen. Unfortunately, safety is not the only outcome at stake. As autonomy cannot be solely safety-related, the more general issues of costs and efficiency of the workforce come into play.

O: I know. There is probably a range of intermediate strategies. Yet the basic principle here is an explicit (though not advertised) trade-off between autonomy for the operators and accountability for management, with the idea that it is for the 
better. The more managers really believe that operators' autonomy will lead to better safety, lesser failures, and subsequently less exposure for themselves, the more they may accept a clear division of labor between operators (taking care of the real stuff) and themselves (taking care of stakeholders).

M: Did you think out all this by yourself?

O: Not really. Such a division of labor has been coined the "organization of hypocrisy" by a Swede (Brunsson 1993).

M: You read more than the newspapers.

O: I read a bit of organization studies literature on the week-ends.

M: While I watch Star Trek again and again!

(They laugh.)

\section{References}

Abbott, A. (2014). The system of professions: An essay on the division of expert labor. University of Chicago Press.

Alvesson, M., \& Gabriel, Y. (2015). Grandiosity in contemporary management and education. Management Learning, 47(4), 464-473.

Boussard, V. D. (2009). L'injonction au professionnalisme. Analyses d'une dynamique plurielle. Rennes, France: Presses Universitaires de Rennes.

Brunsson, N. (1993). Ideas and actions: Justification and hypocrisy as alternatives to control. Accounting, Organizations and Society, 18(6), 489-506.

Hampden-Turner, C. (1990). Corporate culture: From vicious to virtuous circles. London, England: Hutchinson Business Books.

Jackall, R. (1988). Moral Mazes. The world of corporate managers. New York: Oxford University Press.

Vaidyanathan, B. (2012). Professionalism 'from below': mobilization potential in Indian call centres. Work, Employment \& Society, 26(2), 211-227.

Open Access This chapter is licensed under the terms of the Creative Commons Attribution 4.0 International License (http://creativecommons.org/licenses/by/4.0/), which permits use, sharing, adaptation, distribution and reproduction in any medium or format, as long as you give appropriate credit to the original author(s) and the source, provide a link to the Creative Commons license and indicate if changes were made.

The images or other third party material in this chapter are included in the chapter's Creative Commons license, unless indicated otherwise in a credit line to the material. If material is not included in the chapter's Creative Commons license and your intended use is not permitted by statutory regulation or exceeds the permitted use, you will need to obtain permission directly from the copyright holder.

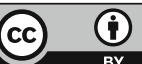

